\title{
"How does work engagement mediate the association between human resources management and organizational performance?"
}

\author{
Gonçalo Pombo iD https://orcid.org/0000-0002-8499-4422 \\ R http://www.researcherid.com/rid/N-9244-2018 \\ Jorge Gomes iD https://orcid.org/0000-0003-0694-2229 \\ R http://www.researcherid.com/rid/D-2231-2017
}

AUTHORS

Gonçalo Pombo and Jorge Gomes (2018). How does work engagement mediate ARTICLE INFO the association between human resources management and organizational performance?. Problems and Perspectives in Management, 16(3), 63-79. doi:10.21511/ppm.16(3).2018.06

DOI http://dx.doi.org/10.21511/ppm.16(3).2018.06

\begin{tabular}{l} 
RELEASED ON \\
RECEIVED ON \\
ACCEPTED ON \\
LICENSE \\
JOURNAL \\
ISSN PRINT \\
\hline ISSN ONLINE \\
\hline PUBLISHER \\
\hline FOUNDER
\end{tabular}

90

NUMBER OF REFERENCES
Wednesday, 18 July 2018

Tuesday, 24 April 2018

Monday, 11 June 2018

\section{(cc) EY-NC}

This work is licensed under a Creative Commons Attribution-NonCommercial 4.0 International License

"Problems and Perspectives in Management"

1727-7051

$1810-5467$

LLC "Consulting Publishing Company "Business Perspectives"

LLC "Consulting Publishing Company "Business Perspectives"
NUMBER OF FIGURES

1
NUMBER OF TABLES

6

(C) The author(s) 2022. This publication is an open access article. 


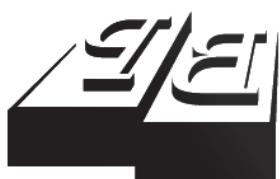

BUSINESS PERSPECTIVES

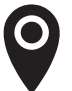

LLC "CPC "Business Perspectives" Hryhorii Skovoroda lane, 10, Sumy, 40022, Ukraine

www.businessperspectives.org

Received on: $24^{\text {th }}$ of April, 2018 Accepted on: $11^{\text {th }}$ of June, 2018

(C) Gonçalo Pombo,

Jorge Gomes, 2018

Gonçalo Pombo, Ph.D student at ISEG - Lisbon School of Economics \& Management, Lisbon, Universidade de Lisboa, Portugal.

Jorge Gomes, Ph.D, ADVANCE/ ISEG - Lisbon School of Economics \& Management, Universidade de Lisboa, Lisbon, Portugal.

\title{
HOW DOES WORK ENGAGEMENT MEDIATE THE ASSOCIATION BETWEEN HUMAN RESOURCES MANAGEMENT AND ORGANIZATIONAL PERFORMANCE?
}

\begin{abstract}
The aim of this paper is to understand how workers' perceptions and behaviors contribute to understanding the association between human resources management (HRM) and organizational performance (OP). Over the past few decades, theory construction has lagged the intermediate linkages between HRM and OP, and, therefore, there are still many unanswered questions with regards to such an association. To sustain the HRM-OP link, the authors highlight the potential influence of employees' work engagement (WE), with the aim of exploring some of the intermediating variables, focusing on the perceptions of employees' attitudes and behaviors. This research emphasizes that line managers have a crucial role to play in stimulating employees' efforts and in shaping HR-related outcomes. Line managers act as crucial intermediaries in determining how HR policies that lead to OP can be designed and administered. Nevertheless, line managers have the capability to disrupt or stimulate the system, which has a significant impact on employees' engagement with the organization. The empirical research is based on a sample of 1,609 employees and 40 organizations and was carried out in two settings. Results suggest that line managers and employees' perceptions of HR policies were positively related to line managers' perceptions of OP. The results also support a path model, whereby WE strengthens HR systems' association with enhanced levels of OP. The discussion reviews the implications of these results and suggests future directions for research.
\end{abstract}

Keywords

JEL Classification

\section{suppression, work engagement}

M12

\section{INTRODUCTION}

As a result of rapid changes and new trends in the business environment, the business world has been facing challenges and demands at a fast pace. Traditional sources of competitive advantage are necessary but are not sufficient (Savaneviciene \& Stankeviciute, 2012a). As a result, research needs to explore new approaches to management and new social dynamics and ways to manage people, as well as to understand how these factors contribute to building and maintaining competitiveness (Gonçalves \& Neves, 2012). Human resource management (HRM) represents a key organizational function to achieve competitive advantage (Boudreau \& Ramstad, 1998), and its contribution to the overall organizational performance $(\mathrm{OP})$ is increasingly acknowledged (Budhwar, 2000). This has led the researchers to look into those HR practices that are associated with OP (e.g., MacDuffie, 1995; Gooderham, Parry, \& Ringdal, 2008), as well as other dimensions in the HRM system that are linked with performance, such as the HR process (e.g., Sanders, Shipton, \& Gomes, 2014), HRM strength "as part of building theoretical rationales" (e.g., Ostroff \& Bowen, 2016,
This is an Open Access article, distributed under the terms of the Creative Commons Attribution-NonCommercial 4.0 International license, which permits re-use, distribution, and reproduction, provided the materials aren't used for commercial purposes and the original work is properly cited. 
pp. 197), or even attributions made of practices (Nishii, Lepak, \& Schneider, 2008). In sum, the general view is that the way people are managed can make a difference (Colakoglu, Lepak, \& Hong, 2006; Adeniji, Osibanjo, Omotayo, \& Abiodun, 2013). Consequently, the current research aims at investigating the relationship between employee-manager perceptions. This study clarifies the gap of employees' work engagement and its relationship to managers' perception of performance. Additionally, results suggest that line managers are responsible for enhancing employees' work engagement, and this has an impact on performance.

Despite this growing evidence of the positive influence of HRM on OP, there are still many unanswered questions with regard to such an association (Purcell, Kinnie, Hutchinson, Rayton, \& Swart, 2003). Some researchers have proposed that HR policies are associated with employees' outcomes (EO) through their influence on employee attitudes and behaviors (e.g., Huselid, 1995; Wright, McCormick, Sherman, \& McMahon, 1999; Wright, McMahan, \& McWilliams, 1994), however, this chain still needs to be empirically supported and explained.

The above association, and indeed the whole research stream is made more difficult by a single fact that has only recently been recognized: the role of employees has been largely neglected, which is quite surprising, as employees are the usual target of most HR policies and practices. Delmotte (2008, p. 107) captures this gap, when he says that "each employee makes his own construction of reality", which means that the content of HRM intentions are probably perceived differently by employees. Therefore, within the same HR policies and practices, different employees will have distinct perceptions of reality, and consequently will exhibit heterogeneity in behaviors and results. This new trend has less to do with denying the role of HR policies and practices, but is more about recognizing that human beings are active players in organizations, and, hence, variety in behaviors and performances are bound to happen everywhere, the whole time.

An ambitious challenge is also to expose the "way", i.e., which HR policies influence OP? Delmotte's quote points to the need to pay attention to the active role played by employees with regards, to the individual and social construction processes within organizations, including the way HR policies influence OP. Savaneviciene and Stankeviciute (2012b) had already alerted to the intervening variables that compose the "black box" in HRM, and subsequently researchers have been proposing various mediation variables in the HRM-OP linkage (Becker, Huselid, Pickus, \& Sprat, 1997; Guest, 1997; Purcell, Kinnie, Hutchinson, Rayton, \& Swart, 2003; Wright \& Nishii, 2006). Some of the previous studies have provided the stepping off point for future developments, focused on the role of line managers. Line managers play an important role in determining the actual form that HR policies take in practice, which is likely to influence OP (Currie \& Procter, 2005). Therefore, line managers become part of the system, with impact on the increase of performance (Hutchinson \& Purcell, 2003). Furthermore, the way employees' attitudes are shaped is the key issue of all HRM and performance linkage models, and there has been a dearth of research evidence based on employees' responses to HR (Macky \& Boxall, 2007).

The current research focuses not only on the HRM content, but also on HR practices, as it assumes that a variety of HR practices interact to shape employees' attitudes (Sanders, Dorenbosch, \& Reuver, 2008). Furthermore, this research also explores how employees contribute to the HRM-OP relationship (Sanders, Shipton, \& Gomes, 2014). This means that HRM is not only about the content of what is conveyed to employees, but it is also about how such content is conveyed to them, as employees' attribution and sense-making processes are affected by the means (especially line managers) used to communicate organizational messages (Kelley, 1973; Weick, 1979). This raises the problem of the match between line managers' views of HRM, and the corresponding views of their employees about the same object. This problem is largely unexplored, and, hence, the main goal of this paper is to analyze the relationship between, on the one hand, the differences in employees'/line managers' perceptions of HRM, and, on the other hand, employees' attitudes, behaviors, and performance. 
This paper is comprised of five sections. The first section reviews the main literature, the key variables, and presents a set of hypotheses. The second part explains the model, as well as the constructs. The third section presents the method, including the data-collecting instruments and analysis procedures. The fourth section presents the results, and the final discusses the results and implications for practice, identifies the limitations, and presents suggestions for future studies.

\section{THEORETICAL BACKGROUND AND HYPOTHESES}

Early theorists writing about HRM have proposed that people have a basic need to understand behaviors and their main causes (Heider, 1958). Therefore, to understand what makes interaction meaningful, one needs to provide and relate actions to subsequent behaviors and attitudes (Kelley \& Michela, 1980). The lack of explanation about how and why HRM influences OP is highlighted as being a critical limitation (Hutchinson, 2013), and it has been labelled by many as the "black box" of HRM.

Searching inside the "black box" requires specifying the HR causal chain (Purcell \& Kinnie, 2007). In recent years, a number of theories have been put forward to explain the process by which HRM impacts on performance (e.g., Becker, Huselid, Pickus, \& Spratt, 1997; Guest, 1997; Appelbaum, Bailey, Berg, \& Kalleberg, 2000; Bowen \& Ostroff, 2004; Wright \& Nishii, 2004; Boxall \& Macky, 2009; Nishii, Lepak, \& Schneider, 2008; Paauwe \& Richardson, 1997). The effectiveness of practices, e.g., the daily enactment of HR philosophies is more important than the occurrence of HR policies (Schuler, 1992), e.g., formal statements of an organization's intent, which serve to directly and partially constrain employees' behavior and their relationship with their employer and their influence on employees' behaviors and attitudes (Hutchinson, 2013). According to Becker, Huselid, Pinckus, and Spratt (1997), HR policies influence the behaviors of employees, which are accordingly reflected in the performance of operational, financial, and share price outcomes. In this way, to understand "the relationship between HR practices and employee outcomes, it is critical to draw logical inferences concerning the HR-performance causal chain as a whole" (Kehoe \& Wright, 2013, p. 369). But these are only inferences, which means that much is still left unexplained regarding how such connections unfold. The problem is amplified by the fact that employees' attitudinal and behavioral responses to a HR system largely depend on employees' perceptions of HR.

To understand this unresolved mystery (Gerhart, 2005), research needs to: i) elaborate on more precise mechanisms; ii) theorize deeply about HR policies; and iii) explore linkages with outcomes (Guest, 1997; Savaneviciene \& Stankeviciute, 2012a).

Following such plea, several theoretical frameworks have contributed to advance further knowledge about the HRM-OP link. For example, Boselie, Dietz, and Boon (2005) suggested that two of the most important theories are the resource-based view (RBV) and the ability, motivation, and opportunity to perform (AMO). While the former has mainly focused on the internal conditions that companies use to foster their competitive advantage, the latter (Appelbaum, Bailey, Berg, \& Kalleberg, 2000) has provided a strong framework for understanding the HRM-OP link.

Just as important as the ability, motivation, and opportunity provided to employees is the focus on their perceptions. From this basic premise, scholars begin to explore attributes about "why" these practices were implemented in the first place (Nishii, Lepak, \& Schneider, 2008) and how they convey employee's expectations to line managers. In fact, employees modify their behaviors because of their calculation of anticipated outcomes (Chen \& Fang, 2008). This calls attention to employees' perceptions in work settings, and it is now the time to highlight the importance of line managers in the HRM-OP linkage, as they may provide different experiences for employees, i.e., by shaping different affective HR reactions, or even enabling the discovery of different kinds of talent. Therefore, research has sought to identify the characteristics of what constitutes a favorable HRM-OP associa- 
tion (Kehoe \& Wright, 2013), focusing on the relationship between employees and line managers, which is finally starting to unlock the "black box" of the relationship between HR policies and EO.

\subsection{The human capital and abilities, motivation, and opportunity (AMO) theory}

Furthermore, there is still missing a congruence or fixed list of HR policies that can be applied in HRM (Paauwe, 2009). Additionally, a broadly theoretical validation for applying practices of HRM is still unclear. Therefore, congruence regarding how HRM should be operationalized is welcome, focusing mainly on promoting workforce ability, motivation, and opportunity to perform (see Appelbaum, Bailey, Berg, \& Kalleberg, 2000; Combs, Liu, Hall, \& Ketchen, 2006), with impact on desired attitudes and behaviors.

The assumption of the AMO theory is that HR policies affect employees' abilities, motivations, and opportunity to participate, which, in turn, positively influences OP (Purcell \& Hutchinson, 2007). Even though some policies contribute to commitment and job satisfaction, they are also mediated by the way management applies them, and by how these are embraced by employees. Guest (1997) suggests that to gain more promising performance, employees not only must be motivated at the individual level, but they also need to possess the necessary and right mix of skills, abilities, and knowledge. According to Harney and Jordan $(2008$, p. 227), theoretical and empirical research "suggest that these three independent system components shape individual and aggregate employee characteristics, thereby contributing to organizational success". Further, organizations need to develop HR practices that motivate staff to achieve wanted skills, abilities and desired behaviors (Gardner, Moynihan, Park, \& Wright, 2001). Consequently, there is a need to promote efforts toward organizational outcomes (Gardner, Moynihan, Park, \& Wright, 2001). Purcell, Kinnie, Hutchinson, Rayton, and Swart (2003) highlight that better performance is likely when employees have the ability and motivation to apply themselves, and when their professional environment provides the opportunity, although, on the other hand, they need to express overall determination (Macky \& Boxall, 2007).
As a result, one can infer that the potential and responsibility for accomplishing OP is embodied in employees. In other words, employees become the central research topic, as performance largely depends on their capability, willingness, and ability to implement, both individually and collectively (in teams, groups, and with their leaders and supervisors).

\subsection{The role of workers}

According to Boselie, Dietz, and Boon (2005), research cannot advance with regard to the HRMOP link, if variables such as worker values, motives, and individual differences remain stubbornly neglected. These concepts are essential to understanding the HRM-OP linkage (Wright \& Boswell, 2002; Guest, 2011). Recently, some authors have started to recognize the role of such concepts by pointing out the way HR policies are communicated and disseminated to employees (Sanders, Shipton, \& Gomes, 2014). Employees, therefore, are an important element in the overall equation, as they actively perceive and interpret organizational activities, including HRM activities (both HR policies and their implementation/ communication). Therefore, workers' behaviors and individual performance are more likely to be the product of three aspects: i) the fit between intended-implemented policies; ii) the support that HR gives to line managers; and iii) line managers-employees sharing commons perceptions (sense giving).

Regarding employees' perceptions, it is important to highlight some of the developments of the last decade. The research of Bowen and Ostroff (2004) provided the stepping off point by suggesting that the HRM-OP link is better understood by focusing on individual and organizational levels, i.e., on the linkages between them, as well as on the role of HR implementers. This means that line managers should be considered in research. Wright and Nishii (2006) argue that there is likely to be a disengagement concerning intended HR policies as reported by line managers and the effect of the actual HR practices on employees. In fact, Nishii, Lepak, and Schneider (2008) point to the fact that as important as the presence of practices in the organization is the perception that key actors hold about the intentions behind such policies. 
The above suggests that the views of line managers about HR should be considered with regard to the HRM-OP linkage, as they are likely to influence employees' perceptions regarding their motivation, abilities, and environments.

\subsection{Growing centralization by line managers}

The responsibility of HRM implementation lies with the fact that line managers should implement HR policies (Nehles, Terhalle, van Riemsdijk, \& Looise, 2010).

Therefore, whilst HR policies in modern organizations are designed by HR professionals, it is line managers who are accountable and responsible for implementing HRM at shop-floor level (Brewster \& Larsen, 1992, p. 412; Kulik \& Bainbridge, 2006). This requires a high level of collaboration between those designing and those implementing and is likely to be an important determinant of success (or failure) (Nehles, Terhalle, van Riemsdijk, \& Looise, 2010). The implementation of HR policies by line managers is likely to have higher impact on employee behavior, motivation, and satisfaction than the design of HR policies by HR professionals, i.e., line managers occupy a central position in accomplishing organization goals and probably have higher and more direct impact on employees' behaviors and attitudes. As line managers are in close contact with employees daily, greater involvement and more effective control can occur (Budhwar \& Sparrow, 1997).

In sum, line managers serve as critical intermediaries, shaping HR practices and overall performance. Good communication helps to keep internal processes running smoothly and helps to create superior relationships with people (Jyoti \& Sharma, 2017).

They can provide employees with much more than just monetary incentives or other tangibles resources, and with their sense giving regarding intangible values and relationships to fully engage employees in their job and in the organization (Gruman \& Saks, 2011; Smith, Plowman, \& Duchon, 2010). The way the job is done, and the speed, care, innovation and style of job delivery, as well as other discretionary behaviors, are all associated with supervision, where line managers play a vital role in setting the direction, i.e., in influencing employee attitudes and behaviors by the way they put policies forward, and by creating a culture of success (Purcell, 2002). This delegation of HRM decisions to line managers will commonly result in a greater scope for disparity and inconsistencies between the policy formulated at HR department level, on the one hand, and, on the other hand, the decisions taken by line managers (McCarthy, Darcy, \& Grady, 2010, p. 160). This means that line managers are faced with a possible role conflict in trying to reconcile their HR responsibilities, on the one hand, while also being open and accommodating to the realities of employee experiences, on the other hand (Harney, 2014). Therefore, line managers play a critical role in influencing employee attitudes and behaviors by the way they put forward designed HR policies into practice, and they can be essential in improving organizations' outcomes (Hutchinson \& Purcell, 2003). Line managers play a key role by changing, reinforcing, or stimulating how employees perceive and interpret HR policies and the whole HR system. Line managers do not "just bring policies to life" (Hutchinson, Kinnie, \& Purcell, 2002, p. 22), but they are compromized, in the sense that the way policies are implemented is related to how employees perceive these policies. This ongoing delegation of HRM implementation to line managers will certainly result in a "greater scope for disparity and inconsistencies between the policy formulated at a senior HR level and the actual decisions taken by line managers" (McCarthy, Darcy, \& Grady, 2010).

In other words, although line managers can respond more effectively at the lower level (Budhwar, 2000), difficulties will also arise, due to various reasons, an example being line managers not willing to take up this responsibility or having to add HRrelated activities to several other actions already in course (Larsen \& Brewster, 2003; Cunningham \& Hyman, 1999; Martins, 2007). Line managers may even suffer exhaustion from assuming responsibility for HR tasks, or they can lack a broader organizational or long-term view. However, it is not unlikely that line managers should develop or adjust their own practices. In some situations, line managers are in close contact with employees and control the key environmental factors that moti- 
vate employees (Latham \& Ernst, 2006). The mediating variable between HR system and employee experiences is the actions and behaviors of line managers. The role of the line manager in fostering a collective culture becomes critical for shaping employee perceptions.

Some limitations may occur when implementing HR policies, such as: i) a lack of desire to execute HR responsibilities; ii) incapability to transfer HR practices to the work floor, which results in an inefficient solution (Nehles, Riemsdijk, Kok, \& Looise, 2006); iii) tasks conditioned when "time is an issue" (Bos-Nehles, Riemsijk, \& Looise, 2013, p. 866); and iv) when contradictory priorities exist between operational tasks, comercial goals, and HR responsabilities (Hope-Hailey, Farndale, \& Truss, 2005; Whittaker \& Marchington, 2003). Consequently, if employees feel that managers have broken their expectation, performance will decline (Coyle-Shapiro \& Kessler, 2002). When employees are not satisfied, there is a tendency that work engagement (WE) and commitment will be low (Ogbuanya \& Chukwu, 2017). However, if employees feel psychological support, then, higher job performance is likely to occur (GouldWilliams, 2007). Employees are understood to show a positive reaction towards their workplace if they perceive fair treatment. Much research focuses on understanding the association between HRM and OP, even though several questions are still without a clear answer. From the above discussion, the assumption is that HR practices are linked to employees and their interpretations of the HRM-OP link (Guest, 1997).

\subsection{Line managers and their commitment to employees}

Additionally, the way line managers implement HR practices will influence employees' perceptions of the effectiveness of HRM, which points to managers' effort and effectiveness in contributing to employees' engagement in the organization (Gilbert, De Winne, \& Sels, 2010). Those employees who experience high levels of WE are more likely to display positive workplace behavior that will benefit the organization (Albdour \& Altarawneh, 2014). Hence, WE have a close relationship with job performance, organizational commitment and job satisfaction (Ogbuanya \& Chukwu, 2017). WE can be defined as "a positive, fulfilling, work-related state of mind. Engagement refers to a more persistent and pervasive, cognitive state that is not focused on any particular object, event, individual, or behavior" (Schaufeli \& Bakker, 2003, pp. 4-5) When HR makes sense to employees, work-related attitudes and behaviors turn out to be more effective (Sanders, Shipton, \& Gomes, 2014). However, the influence on each employee needs to be addressed differently. Differences in perceptions can be a result of employees making sense of the practices in their knowledge spheres, which are affected by their background. Attributions made by employees of HR practices will determine the level of acceptance. This means that employees' expectations are an important proposition for the interpretation gap (Piening, Baluch, \& Ridder, 2014). Line managers need to connect espoused values with enacted values, i.e., by constantly shaping how employees view the organization through "everyday sense giving" (Smith, Plowman, \& Duchon, 2010).

When line managers are willing to take up the responsibility of putting into practice the designed policies, then, supportive work environment will emerge. Furthermore, when successfully "executing performance appraisals, giving feedback, offering training to execute the job more accurately, and providing back up when a colleague falls sick will all give employees the feeling that they are supported and encouraged by their line managers to execute their job effectively, now, and in the future" (Gilbert, De Winne, \& Sels, 2010, p. 7). Line managers can and should emphasize the importance of a positive teamwork environment at every level of the organization. The goal is to achieve discretionary behavior, i.e., employees working with diligence and dedication, taking the employee-organization relationship to the next level of trust, and developing a psychological contract (Besanko, Deanove, Shanley, \& Schefer, 2013). Nevertheless, the perception of a teamwork environment should be a one-on-one relationship between, on the one hand, line managers and each of their employees, and, on the other hand, employees among themselves. Additionally, a positive workplace is essential for employees to get involved with the organization's mission and values. Furthermore, an upbeat team-based environment characterized by sharing and open discussions will allow employ- 
ees to contribute with their views and perspectives, and, hence, organizational goals are more likely to be attained. Even so, the way employees react and perceive line managers' intentions will be heavily affected by the relationship between the two (Boxall \& Purcell, 2008). Based on this statement, we can formulate the following hypotheses:

H1: There is a relationship between employee-manager perceptual differences regarding HR policies, and manager's perception of performance. More specifically, the smaller the difference between employees' perceptions of HR policies and managers' perceptions of HR policies, the higher the managers' perceptions of performance.

H2: There is a positive relationship between employee-manager perceptual differences regarding HR policies and employees' work engagement. More specifically, the smaller the difference between employees' perceptions of HR policies and managers' perceptions of $H R$ policies, the higher the employees' work engagement.

H3: There is a positive relationship between employees' work engagement and manager's perception of performance.

H4: Employees' work engagement mediates the relationship between employee-manager perceptual differences regarding $H R$ policies (independent variable) and manager's perception of performance (outcome variable).

\subsection{Research framework}

Figure 1 presents the overall representation of the theoretical framework that depicts the relationship between HR policies, WE, and OP.

\subsection{Mediation model}

Supported by the literature review, the proposed mediation model is aligned with the guidelines provided by Baron and Kenny (1986) concerning the definition and status of a mediator. The mediation model explains why employee-manager perceptual differences regarding $\mathrm{HR}$ policies are related to managers' perception of performance, in which one variable is hypothesized to be intermediating the relation between an independent antecedent and an outcome (Fairchild \& Mackinnon, 2009).

This model, presented in Figure 1, has three variables and two causal paths feeding into the outcome variable $(Y)$, i.e., the direct impact of the independent variable $(X)$ on the "path $c$ ", and the impact of the mediator $(M)$ on the "path b" (Baron \& Kenny, 1986).

\section{METHOD}

According to Baron and Kenny (1986, p. 1176), a variable acts as a mediator when it follows these criteria: i) employee-manager perceptual differences regarding $\mathrm{HR}$ policies are correlated with managers' perception of performance (path c), i.e., a simple regression analysis with $X$ predicting $Y$

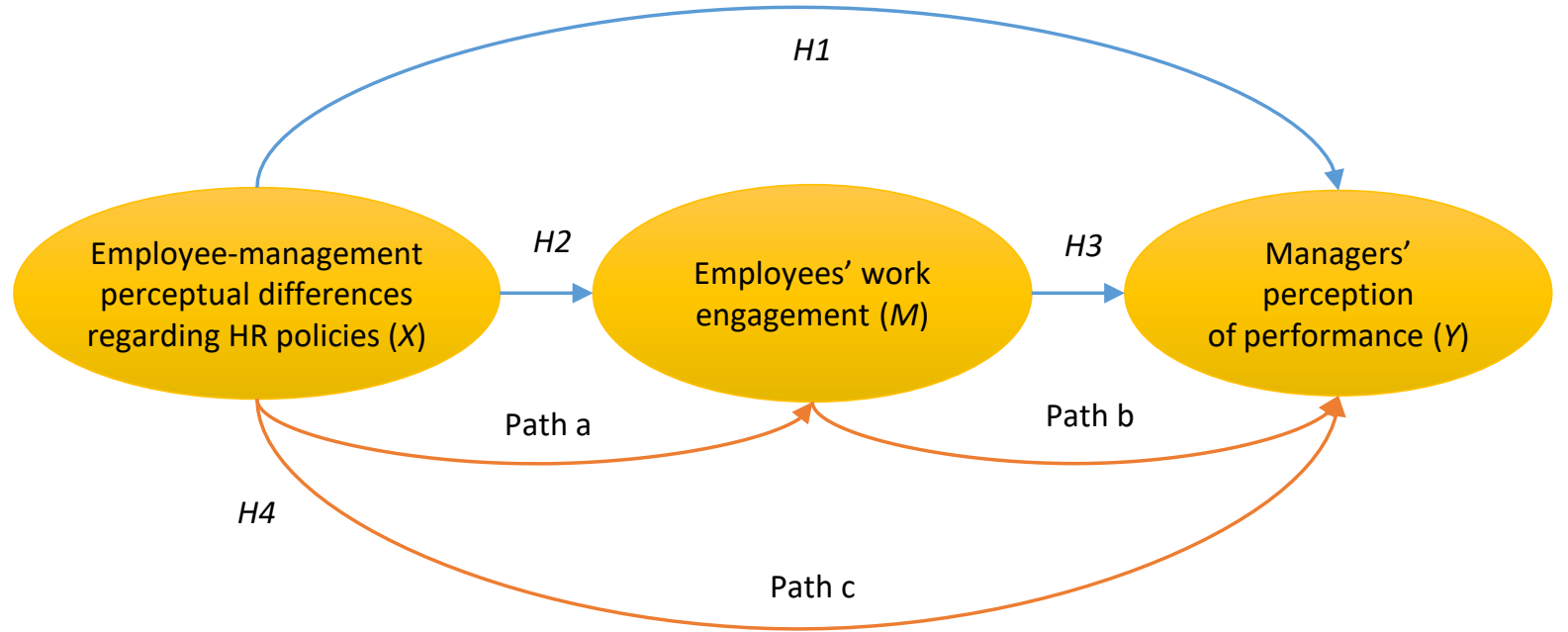

Figure 1. Research framework 
to test: $Y=\beta_{0}+\beta_{1} X+e$; ii) employee-manager perceptual differences regarding HR policies are correlated with employees' work engagement, using the employees' work engagement as a dependent variable in the regression equation (path a), i.e., a simple regression analysis with $X$ predicting $M$ to test: $M=\beta_{0}+\beta_{1} X+e$; iii) employees' work engagement is correlated with managers' perception of performance (path b), i.e., a simple regression analysis with $M$ predicting $Y$ to test: $Y=\beta_{0}+\beta_{1} M+e$; and iv) employees' work engagement affects managers' perception of performance, using managers' perception of performance as the dependent variable in a regression equation and employee-manager perceptual differences regarding HR policies and employees' work engagement as independent ones, i.e., a multiple regression analysis with $X$ predicting $Y$ (path c') and $M$ predicting $Y$ (path b): $Y=\beta_{0}+\beta_{1} X+\beta_{2} M+e$. Lastly, in step iv), mediation is likely to be supported if the effect of employees' work engagement (path b) remains significant after controlling for employee-manager perceptual differences regarding HR policies. If employee-manager perceptual differences regarding HR policies are not statistically significant, when employees' work engagement is controlled, then, the finding supports total mediation. However, if employee-manager perceptual differences regarding HR policies are significant, then, the finding supports partial mediation.

Sobel (1982) tests were also conducted to further support the mediation model, as proposed. This test is designed to assess whether a mediating variable (employees' work engagement) carries the effects of the independent variable (employee-manager perceptual differences regarding HR policies) to a dependent variable (managers' perception of performance). The computed statistic measures the indirect effect of the independent variable on the dependent variable by way of the mediator. Reported $p$-values are obtained from the unit normal distribution, under the assumption of a two-tailed test of the hypothesis that the mediated effect equals zero in the population using -1.96 as the critical value, which contains the central $95 \%$ of the unit normal distribution (Preacher \& Hayes, 2004). Under this test, a significant $p$-value indicates support for mediation. Finally, Aroian's $(1944 / 1947)$ test of mediation was used to further verify the results, as provided in Table 5 .

\section{CONSTRUCTS AND MEASURES}

\section{Employee-manager perceptual differences regarding HR policies}

We adhere to the research stream on HRM-OP link that uses for the first construct the differences between line managers and employees, as far as HR policies are concerned. The appropriateness of deviation scores for estimating differences between measures units continues to be a source of diversities (Edwards, 2001). However, according to Smith and Tisak (1993), deviation scores are both reliable and unbiased. Weighing arguments by both positions and recognizing the grounding of our research, we judged deviation scores appropriate for use.

These were calculated based on the research by Sanders, Dorenbosch and Reuver (2008), in which line managers and employees were asked to indicate, on a six-point scale, their level of agreement with the content of 17 sentences linked to five HRM practices/policies: i) extensive training; ii) internal mobility; iii) participation; iv) pay performance; and v) employee security. Sample items include "I am often asked to participate in decisions".

Upon data collection, the database was organized in three steps. In the first step, data were arranged by organization (40 organizations): for each organization, the researchers calculated the mean of line managers' answers to the 17 items; in the second step, the average value for all managers within each organization was calculated. Steps 1 and 2 resulted in 40 different values, which denoted the mean average of manager's perceptions as far as the aggregate 17 items were concerned.

In the third step, these values were used to calculate the perceptual difference between line managers and employees: for each organization, the researchers calculated the difference between each employee's aggregated value regarding the 17 items, and the correspondent managers' aggregated value. This resulted in a new variable: "employee-manager perceptual differences regarding HR policies". 


\section{Employees' work engagement}

The second construct is employees' work engagement, measured using Schaufeli and Bakker's (2003) scale. The employees' work engagement scale consists of nine items, and employees were asked to indicate, on a six-point scale, their level of agreement with three constituting aspects of WE: i) vigor; ii) dedication; and iii) absorption. Each participant indicated the extent to which he/ she agreed with the statements, such as "I really "throw" myself into my job". An aggregated measure of WE was used in the hypotheses testing.

\section{Managers' perception of performance}

Finally, the six dimensions of managers' perception of performance (customer satisfaction; growth; market share; product/service to market; customer retention; new customer attraction) were measured using indexes previously offered by other researchers, such as Tzafrir (2005), and Dany, Guedri, and Hatt (2008). Such indexes require respondents to indicate the extent to which they perceive organizational performance in comparison to competitors. These data were collected regarding line managers' perception only and are labelled "managers' perception of performance". Table 1 shows the constructs and their operational definition.

Table 1. Operationalization of the research variables

\begin{tabular}{|c|c|c|c|}
\hline Variables & Author & Scales & Items \\
\hline \multirow{5}{*}{$\begin{array}{l:}\text { Employee- } \\
\text { manager } \\
\text { perceptual } \\
\text { differences } \\
\text { regarding HR } \\
\text { policies }\end{array}$} & \multirow{5}{*}{$\begin{array}{l}\text { Sanders, } \\
\text { Dorenbosch, } \\
\text { and Reuver } \\
(2008)\end{array}$} & Extensive training & \multirow{5}{*}{17} \\
\hline & & Internal mobility & \\
\hline & & Participation & \\
\hline & & Pay performance & \\
\hline & & Employee security & \\
\hline \multirow{3}{*}{$\begin{array}{l}\text { Employees' } \\
\text { work } \\
\text { engagement }\end{array}$} & \multirow{3}{*}{$\begin{array}{l}\text { Schaufeli and } \\
\text { Bakker (2003) }\end{array}$} & Vigor & \multirow{3}{*}{9} \\
\hline & & Dedication & \\
\hline & & Absorption & \\
\hline \multirow{6}{*}{$\begin{array}{l}\text { Managers' } \\
\text { perception } \\
\text { of } \\
\text { performance }\end{array}$} & \multirow{6}{*}{$\begin{array}{l}\text { Based on } \\
\text { the work } \\
\text { of several } \\
\text { researchers } \\
\text { such as Tzafir } \\
\text { (2005), and } \\
\text { Dany, Guedri, } \\
\text { and Hatt } \\
\text { (2008) }\end{array}$} & Customer satisfaction & \multirow{6}{*}{6} \\
\hline & & Growth & \\
\hline & & Market share & \\
\hline & & $\begin{array}{l}\text { Product/service to } \\
\text { market }\end{array}$ & \\
\hline & & Customer retention & \\
\hline & & $\begin{array}{l}\text { New customer } \\
\text { attraction }\end{array}$ & \\
\hline
\end{tabular}

\section{Internal consistency}

Table 2 shows the values of Cronbach's alpha for all variables. Cronbach's alpha is a measure of internal consistency, i.e., how closely related a set of items are as a group. The alpha coefficients for the three items are higher than 0.88 , suggesting that the items have high internal consistency.

Table 2. Cronbach's alpha

\begin{tabular}{l|c|c}
\hline \multicolumn{1}{c|}{ Variable } & $\begin{array}{c}\text { Items } \\
\text { retained }\end{array}$ & $\begin{array}{c}\text { Cronbach's } \\
\text { alpha }\end{array}$ \\
\hline $\begin{array}{l}\text { Employee-manager perceptual } \\
\text { differences regarding HR } \\
\text { policies }\end{array}$ & 17 & 0.910 \\
\hline $\begin{array}{l}\text { Employees' work engagement } \\
\text { Managers' perception of } \\
\text { performance }\end{array}$ & 09 & 0.881 \\
\hline
\end{tabular}

\section{Sample}

The data come from a survey of employees and line managers from 32 organizations in Portugal, four organizations in Norway and four organizations in Denmark, from several industry sectors, ranging from energy and water to transport, communication, and finance and business. The justification for targeting employees and line managers in these three countries is to embrace diversity in the service, production, and consumption services sectors. According to the country destination, the questionnaires were administered in two languages, i.e., Portuguese or English.

There were 1,855 sets of questionnaires distributed to line managers and employees, of which 264 are line managers and 1,345 are employees, i.e., total of 1,609 sets of questionnaires were returned, giving a response rate of $86.74 \%$. However, after checking differences between employees' perceptions of HR policies and managers' perceptions of HR policies, and removing outliers, only 1,331 questionnaires were properly completed and accepted for the study. More than $50 \%$ of participants are between 25 and 40 years old, and the majority have an academic degree.

The data obtained were analyzed for reliability, validity, adequacy, and suitability in answering research questions. For this reason, the data are expected to enhance the reliability and validity of the study. 


\section{RESULTS}

\subsection{Descriptive statistics and correlations}

Table 3 presents the descriptive statistics and correlations of the variables comprising the study. The analysis of the results brings out the perceptual differences regarding $\mathrm{HR}$ policies between employees and line managers (mean $=0.424$ ). As expected, HR policies are related to WE $(r=0.369$, $p=0.05)$ and $\mathrm{OP}(r=0.269, p=0.05)$.

Table 3. Descriptive statistics and correlation between variables

\begin{tabular}{|c|c|c|c|c|c|}
\hline \multirow{2}{*}{ Variable } & \multicolumn{2}{|c|}{$\begin{array}{c}\text { Descriptive } \\
\text { statistics }\end{array}$} & \multicolumn{3}{|c|}{ Correlations (R) } \\
\hline & Mean & $\begin{array}{l}\text { Std. } \\
\text { dev. }\end{array}$ & HR & WE & OP \\
\hline $\begin{array}{l}\text { Employee-manager } \\
\text { perceptual } \\
\text { differences regarding } \\
\text { HR policies }\end{array}$ & 0.424 & 0.817 & 1 & & \\
\hline $\begin{array}{l}\text { Employees' work } \\
\text { engagement }\end{array}$ & 4.388 & 0.787 & $0.369 *$ & 1 & \\
\hline $\begin{array}{l}\text { Managers' } \\
\text { perception of } \\
\text { performance }\end{array}$ & 4.497 & 0.641 & $0.269 *$ & $0.322 *$ & 1 \\
\hline
\end{tabular}

Note: ${ }^{\star}$ Significant at the 0.1 level (2-tailed).

\subsection{Assumptions for a multiple regression}

Statistical tests rely upon certain assumptions about the variables used in the analysis. Specifically, we will discuss the assumptions of normality, e.g., the Mahalanobis distance test and independence of sampling, e.g., the Durbin-Watson test for independence, linearity, homoscedasticity, and multicollinearity.

Absence of multivariate outliers is checked by assessing Mahalanobis distances among the participants. As the obtained result was 13.512, it means that the critical value of 13.816 is met, which indicates the normality of the data.

The second assumption is the Durbin-Watson test for independence. The Durbin-Watson test is a measure of autocorrelation (also called serial correlation) in residuals from regression analysis. To be considered uncorrelated, the required Durbin-Watson statistic should be between 1.5 and 2.5 (Dufour \& Dagenais, 1985). The Durbin-
Watson $d=1.675$ is between the two critical values of $1.5<d<2.5$, and, therefore, we can assume that there is no first order linear auto-correlation in the data.

The next assumption is linearity. A linearity test aims to determine if the relationship between independent variables and the dependent variable is linear. If there is good research in the regression model, then, there should be a linear relationship between the independent variable and dependent variable. The linearity assumption can be tested with scatter plots. The obtained scatter plot follows a linear pattern (i.e., not a curvilinear pattern), which shows that linearity assumption has been met.

The next assumption is homocesdasticity. The assumption of equal variances (i.e., assumption of homoscedasticity) assumes that different samples have the same variance, even if they came from different populations. Breusch-Pagan ( $\mathrm{LM}=3.773$; Sig. $=0.152)$ and Koenker $(\mathrm{LM}=4.181$; Sig. $=0.124)$ test the null hypothesis that error variances are all equal versus the alternative that error variances are a multiplicative function of one or more variables. Therefore, we do not reject the null hypothesis and can assume that the error variances are all equal.

Finally, the last assumption is multicollinearity. Multicollinearity is a state of very high inter-correlations or inter-associations among independent variables. It is, therefore, a type of disturbance in the data, and if present in the data, the statistical inferences may not be reliable. Collinearity statistics output reveals tolerance higher than 0.1 , e.g., 0.864 for HR policies and WE and a variance inflation factor lower than 10.00, e.g., 1.158 for HR policies and $\mathrm{WE}$, meaning that we do not violate this assumption. Therefore, multicollinearity does not remain a dire problem in this study.

\subsection{Hypotheses testing}

A two-step regression analysis was performed for each dependent variable. The first regression analysis was carried out to determine the relationship between employee-manager perceptual differences regarding HR policies and managers' perception of performance, as provided in Table 
3. The $R$-square value indicates that $7.2 \%$ of variance in managers' perception of performance can be explained by employee-manager perceptual differences regarding HR policies $(R=0.269$; $F=103.883 ; p<0.05)$, i.e., path $c$. The regression results in Table 3 also show a very similar relationship between path a and $\mathrm{b}$, i.e., the $R$-square value indicates that $13.6 \%$ of variance in employees' work engagement can be explained by employee-manager perceptual differences regarding HR policies $(R=0.369 ; F=209.512 ; p<0.05)$ and $10.4 \%$ of variance in managers' perception of performance can be explained by employees' work engagement $(R=0.322 ; F=154.237 ; p<0.05)$, thus, supporting hypotheses $\mathrm{H} 1, \mathrm{H} 2$ and $\mathrm{H} 3$.

Table 4. Regression analysis

\begin{tabular}{|c|c|c|c|c|c|c|}
\hline 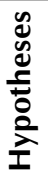 & $\frac{5}{\pi}$ & $\frac{\frac{0}{2}}{\frac{7}{3}}$ & $\beta$ & $\mathbf{t}$ & Sig.* & 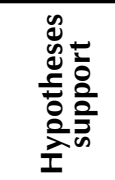 \\
\hline 1 & C & 103.883 & 0.0746 & 10.192 & 0.000 & Asserted \\
\hline 2 & $\mathrm{a}$ & 209.512 & -0.1867 & -14.475 & 0.000 & Asserted \\
\hline 3 & $\mathrm{~b}$ & 154.237 & 0.176 & 11.419 & 0.000 & Asserted \\
\hline
\end{tabular}

Note: ${ }^{*}$ Significant at the 0.05 level (2-tailed).

Four conditions are required for the existence of an effect of mediation (Baron \& Kenny, 1986), the first three conditions are reflected in Table 4. First, the independent variable, employee-manager perceptual differences regarding HR policies, and the managers' perception of performance, dependent variable, are correlated $(0.0746, p<0.05)$. Second, the independent variable, employee-manager perceptual differences regarding HR policies, and the employees' work engagement, mediator, are correlated $(-0.1867, p<0.05)$. Third, the employees' work engagement, mediator, and the managers' perception of performance, dependent variable, are correlated $(0.176, p<0.05)$. Lastly, the effect of the independent variable on the dependent variable should change when the mediating variable is introduced. Table 6 offers a more detailed explanation about the last effect.

\subsection{Mediating effect of the hypothesized model}

To test if a mediator carries the influence of an independent variable to a dependent variable, we used the equation drawn from MacKinnon and
Dwyer (1993) and from MacKinnon, Warsi, and Dwyer (1995):

i) Sobel test equation:

$$
z \text {-value }=\frac{a \cdot b}{S Q R T\left(b_{2} \cdot s a_{2}+a_{2} \cdot s b_{2}\right)} ;
$$

ii) Aroian test equation:

$$
z \text {-value }=\frac{a \cdot b}{S Q R T\left(b_{2} \cdot s a_{2}+a_{2} \cdot s b_{2}+s a_{2} \cdot s b_{2}\right)}
$$

iii) Goodman test equation:

$$
z \text {-value }=\frac{a \cdot b}{S Q R T\left(b_{2} \cdot s a_{2}+a_{2} \cdot s b_{2}-s a_{2} \cdot s b_{2}\right)} .
$$

Table 5. Calculation for mediation tests

\begin{tabular}{c|c:c:c}
\hline Test & Test statistic & Std. error & Sig. $^{*}$ \\
\hline Sobel & -9.46589007 & 0.00347690 & 0.00000000 \\
\hdashline Aroian & -9.45294819 & 0.00348167 & 0.00000000 \\
Goodman & -9.47888525 & 0.00347214 & 0.00000000 \\
\hline
\end{tabular}

Note: ${ }^{*}$ Significant at the 0.05 level (2-tailed).

The reported $p$-values (rounded to 8 decimal places) are drawn from the unit normal distribution under the assumption of a two-tailed $z$-test of the hypothesis that the mediated effect equals zero in the population. +/- 1.96 are the critical values of the test ratio, which contain the central $95 \%$ of the unit normal distribution. According to the $p$-value in Table 5, all the three tests confirm that there is mediation, i.e., the coefficient is significant.

We used the macro process for SPSS, version 2.15, written by Andrew F. Hayes. The macro process applies a bootstrapping test, i.e., a non-parametric method based on resampling with a replacement, which, in this case, was done 5,000 times. From each of these samples, the indirect effect is calculated and a sampling distribution can be empirically generated. A confidence interval is calculated, and it is checked to determine if zero is in the interval. If zero is not in the interval, then, the researcher can be confident that the indirect effect is different from zero.

Table 6 shows the last condition, i.e., the step iv) described in Figure 1, which is required for the existence of an effect of mediation (Baron \& Kenny, 1986). The effect of the independent variable (e.g., 
employee-manager perceptual differences regarding HR policies) on the dependent variable (e.g., managers' perception of performance) should decrease for a partial mediation, or even approach zero for a total mediation, when the mediating variable (e.g., employees' work engagement) is introduced. The effect of employee-manager perceptual differences regarding HR policies on managers' perception of performance does not reduce the effect of the main effect, but rather increases it. Contrary to expectations, the effect of the independent variable on the dependent variable does not decrease for a partial mediation, or even approach zero for a total mediation. This means that the direct effect is subsumed by the mediation effect.

Table 6. Inconsistent mediation

\begin{tabular}{c|c:c:c}
\hline Path effect & Coeff. & $\mathbf{t}$ & Sig. \\
\hline Path c' & 0.1245 & 17.922 & 0.000 \\
\hline \multicolumn{4}{c}{ a. Direct effect of $\mathrm{X}$ on $\mathrm{Y}$} \\
\hline Path a & -0.1867 & -14.4745 & 0.000 \\
\hline Path b & 0.2673 & 19.472 & 0.000 \\
\hline \multicolumn{4}{c}{ b. Indirect effect of X on Y } \\
\hline
\end{tabular}

Note: Output from process procedure for SPSS, version 2.15, written by Andrew F. Hayes.

Table 6 reveals what MacKinnon, Fairchild, and Fritz (2007) refer to as "inconsistent mediation". The direct effect of employee-manager perceptual differences regarding HR policies on managers' perception of performance is, thus, likely to be overestimated, because the indirect effect will tend to be equal to the sum of total effects. The total effect is equal to the sum of direct and indirect effects. This pattern of coefficients indicates the presence of inconsistent mediation (i.e., a suppres- sor effect). Suppression focuses on the adjustment of the relationship between the independent and dependent variables, but in an unusual manner, as the size of the effect increases when the suppressor variable is added. In the mediation framework, a suppressor model corresponds to an inconsistent mediation model, where the mediated and direct effect have opposite signs. In other words, it cannot be directly calculated, as shown in Table 6 . Table 7 reveals the effects of the mediator in the research model, ignoring positive or negative relations.

Table 7. Effects of mediator in the research model

\begin{tabular}{l|c:c|c}
\hline $\begin{array}{c}\text { Endogenous variable } \\
\text { (managers' perception } \\
\text { of performance) }\end{array}$ & $\begin{array}{c}\text { Indirect } \\
\text { effect }\end{array}$ & $\begin{array}{c}\text { Direct } \\
\text { effect }\end{array}$ & $\begin{array}{c}\text { Total } \\
\text { effect }\end{array}$ \\
\hline $\begin{array}{l}\text { Employee-manager } \\
\text { perceptual differences } \\
\text { regarding HR policies }\end{array}$ & 0.0499 & 0.0247 & 0.0746 \\
\hline
\end{tabular}

In conclusion, the outputs mean that the mediator, employees' work engagement, significantly explained that managers' perception of performance was determined by the predictor (employee-manager perceptual differences regarding HR policies) with the help of the mediator, i.e., employees' work engagement does mediate the relationship between employee-manager perceptual differences regarding HR policies and managers' perception of performance.

It was also found that perceptions of HR policies rated by line managers were positively related to employees' perceptions and significantly associated with each other. These results are likely related to leadership and further highlight the importance of developing good relationships among the staff, e.g., line managers and employees.

\section{DISCUSSION AND CONCLUSION}

This paper examined how employee-manager perceptual differences regarding HR policies, employees' work engagement and managers' perception of performance are related and inquired as to whether the relationship between employee-manager perceptual differences regarding HR policies and employees' work engagement affected managers' perception of performance. Finally, it analyzed the relationship between the match between employees and line managers' perceptions of HR policies. This study contributes to the unresolved "black box" mystery and fulfils the gap of employees' work engagement and its relationship to managers' perception of performance. This paper goes beyond the classic vision of the mediating role of employees' work engagement to investigate the relationship between employee-manager perceptual differences regarding HR policies and managers' perception of performance, by exploring employees' and line managers' perceptions of HR policies. 
Specifically, our first result indicates clear support for the assumption that employee-manager perceptual differences regarding HR policies are related to managers' perception of performance (i.e., path c), which is consistent with most of the literature (Huselid, 1995; MacDuffie, 1995; Guest, 1997; Wright \& Nishii, 2006; Savaneviciene \& Stankeviciute, 2012a; Hutchinson, 2013; Sanders, Shipton, \& Gomes, 2014). Additionally, the study revealed an optimistic and significant relationship between employees' and managers' perceptual differences regarding HR policies and employees' work engagement (i.e., path a), which is the same for employees' work engagement and managers' perception of performance (i.e., path b), thus, supporting part of the condition of mediation suggested by Barron and Kenny (1986). However, when the mediating variable is introduced, the effect of employee-manager perceptual differences regarding HR policies on managers' perception of performance was reduced, leading us to conclude that there is a mediation effect. In an inconsistent mediation, a suppression effect would be present when the direct and mediated effects of an independent variable on a dependent variable have opposite signs (Cliff \& Earleywine, 1994; Tzelgov \& Henik, 1991). In our model, we have an inconsistent mediation (Davis, 1985). The results of this study show that the effect of the employee-manager perceptual differences regarding HR policies on managers' perception of performance changes drastically. However, because of the inconsistent mediation phenomenon, i.e., suppression, it does not reduce the effect of the main effect, but increases it (see Table 6). There is an adjustment of the relationship between the independent and dependent variables, but in an unusual way, where the size of the effect increases when the suppressor variable is added, meaning that the direct effect is subsumed by the mediation effect.

When HR policies are designed by HR professionals, the goal is to stimulate employees' skills and capabilities by promoting right behaviors. Moreover, employees' work engagement does mediate the relationship between employee-manager perceptual differences regarding HR policies and manager's perception of performance. However, we cannot disregard that leadership by front line managers has a crucial role in applying employees' efforts and ability to elicit discretionary behavior. In sum, line managers shape the actual employee perceptions regarding HR policies and, moreover, they shape overall performance, and, hence, provide employees with support and resources to fully engage in their job and in the organization (Gruman \& Saks, 2011). However, this does not necessarily mean achieving OP through employees' work engagement, as every so often, ambitious HR policies may result in long-term exhaustion and diminished interest in work. The assumption is that when HRM makes sense to employees, work-related attitudes and behaviors will turn out to be more effective (Sanders, Shipton, \& Gomes, 2014). Additionally, studies point to the importance of matching employees' and line managers' perceptions of HR policies (Nishii, Lepak, \& Schneider, 2008; Wright \& Nishii, 2006), as this will allow organizations to achieve better managers' perception of performance.

Furthermore, the empirical work has demonstrated that employees' perceptions of HR policies significantly vary from managerial reports of the HR policies in use (Liao, Toya, Lepak, \& Hong, 2009). Employees' perceptions of HR policies necessarily follow managers' HR policy implementation (Nishii \& Wright, 2008). In this regard, results do not evidence different employees' and line managers' perceptions of HRM. This alignment of perceptions is most likely to occur at the beginning of the relationship, when line managers clarify and interpret HR policies, i.e., line manager's explanations are more likely to influence employees to count on such information and to construct expected HR policy reality. By concentrating employee's attentions on certain practices, line managers are structuring employees' attention (Salancik \& Pfeffer, 1978). Therefore, further knowledge about which practices should be considered to enhance employees' and line managers' perceptions and how those practices are perceived is needed. Consequently, this research has both theoretical and practical reference value.

\section{Implications for practice}

Our results suggest that if line managers engage themselves in assuming their HRM role, they can be a powerful partner of the HR department in enhancing employees' work engagement, and this has an impact on performance. Additionally, as line manager's enactment of perceptions regarding HR policies 
and relations-oriented behavior turn out to have an influence on employees, HR departments should work together with line managers and provide enough support and advice to line managers in their leadership tasks. Training activities should also embrace leadership development program to develop the leadership skills of line managers. Additionally, researchers should pay more attention to contextual issues, e.g., the size of the organization may emphasize the leading role of line managers. Specifically, the configuration of these factors, and others, may be used as a framework to enrich future research.

\section{Limitations of the study and future research}

Although this research has made several contributions to the knowledge, it has several limitations, as follow: a) the study measures the variables at a single point of time, i.e., cross-sectional design. Therefore, changes in the relationship between line managers' and employees' perceptions were not covered in the study; b) it only includes individuals from Portugal, Norway and Denmark, thus, the generalizability of the results is restricted; and lastly c) this study has only identified perceptual differences regarding HR policies.

Future research could examine the conceptual model used in this study, but with a larger sample size, in order that the outcomes can be generalized to a larger population. For the purpose of association, it would be interesting to replicate this study in a longitudinal design, so that it could be determined whether the match employees' and line managers' perceptions in multiple variables, e.g., employees' and managers' perceptions of work engagement and performance, are conditions for shaping the actual form that transforms overall performance.

\section{ACKNOWLEDGEMENT}

We gratefully acknowledge financial support from FCT - Fundação para a Ciência e Tecnologia (Portugal), national funding through research grant UID/SOC/04521/2013.

\section{REFERENCES}

1. Adeniji, A. A., Osibanjo, A. O., \& Abiodun, A. J. (2013). Organisational change and human resource management interventions: An investigation of the Nigerian Banking Industry. Serbian Journal of Management, 8(2), 2-16.

2. Albdour, A. A., \& Altarawneh, I. I. (2014). Employee engagement and organisational commitment: Evidence from Jordan. International Journal of Business, 19(2), 1083-4346.

3. Appelbaum, E., Bailey, T., Berg, P., \& Kalleberg, A. L. (2000). Manufacturing advantage: Why high-performance work systems pay off. London: Cornell University Press.

4. Aroian, L. A. (1944/1947). The probability function of the product of two normally distributed variables. Annals of Mathematical Statistics, 18, 265-271.

5. Baron, R. M., \& Kenny, D. A. (1986). The moderatormediator variable distinction in social psychological research: Conceptual, strategic and statistical considerations. Journal of Personality and Social Psychology, 51, 1173-1182.

6. Becker, B. E., Huselid, M. A., Pickus, P. S., \& Spratt, M. (1997). Human Resource as a source of shareholder value: Research and recommendations. Human Resource Management, 36, 39-47.

7. Besanko, D., Deanove, D., Shanley, M., \& Schefer, S. (2013). Economics of strategy (Vol. 6). New York: John Willey \& Sons, Inc.

8. Boselie, P., Dietz, G., \& Boon, C. (2005). Commonalities and contradictions in HRM and performance. Human Resource Management Journal, 15(1), 67-94.

9. Bos-Nehles, A. C., Riemsijk, M. J., \& Looise, J. K. (2013). Employee perceptions of linemanagement performance: applying the AMO theory to explain the effectiveness of line managers' HRM implementation. Human Resource Management, 52(6), 861-877.

10. Boudreau, J. W., \& Ramstad, P. M. (1998). Human resource metrics: Can measures be strategic? CARHS Working Paper Series, 10, $1-28$.

11. Bowen, D. E., \& Ostroff, C. (2004). Understanding HRM-firm performance linkages: The role of the "strength" of the HRM system. Academy of Management Review, 29, 203-221. 
12. Boxall, P., \& Macky, K. (2009). Research and theory in highperformance work systems: progressing the high-involvement stream. Human Resource Management Journal, 19(1), 3-23.

13. Boxall, P., \& Purcell, J. (2008). Strategy and Human Resource Management (2nd ed.). New York: Palgrave Macmillan.

14. Brewster, C., \& Larsen, H. H. (1992). Human Resource Management in Europe: Evidence from ten countries. The International Journal of Human Resource Management, 3, 409-433.

15. Budhwar, P. S. (2000). Evaluating levels of strategic integration and devolvement of human resources management in the UK. Personnel Review, 29(2), 141-157.

16. Budhwar, P. S., \& Sparrow, P. R. (1997). Evaluating levels of strategic integration and devolvement of human resource management in India. The International Journal of Human Resource Management, 8(4), 476-494.

17. Chen, Y.-Y., \& Fang, W. (2008). The moderating effect of impression management on the organizational politicsperformance relationship. Journal of Business Ethics, 73, 263-277.

18. Cliff, N., \& Earleywine, M. (1994). All predictors are "mediators" unless the other predictor is a "suppressor". Unpublished manuscript.

19. Colakoglu, S., Lepak, D., \& Hong, Y. (2006). Measuring HRM effectiveness: considering multiple stake holders in a global context. Human Resource Management Review, 16, 209-218.

20. Coyle-Shapiro, J., \& Kessler, I. (2002). Reciprocity through the lens of the psychological contract: Employee and Employer perspectives. European Journal of Work and Organisational Psychology, 11(1), 1-18.

21. Cunningham, I., \& Hyman, J. (1999). Devolving human resources responsibilities to the line. Personnel Review, 28(1/2), 9-27.

22. Currie, G., \& Procter, S. (2005). The antecedents of middle managers' strategic contribution: The case of a professional bureaucracy. Journal of Management Studies, 42(7), 13251356.

23. Dany, F., Guedri, Z., \& Hatt, F. (2008). New Insights into the Link between HRM Integration and Organizational Performance: The Moderating Role of Influence Distribution Between HRM Specialists and Line Managers. The International Journal of Human Resources Management, 19(11), 2095-2112.

24. Davis, J. A. (1985). The logic of causal order (Quantitative Applications in Social Sciences). Beverly Hills, CA: SAGE Publications, Inc.

25. Delmotte, J. (2008). Evaluating the HR function: Empirical studies on HRM architecture and HRM system strength. Doct. K.U. Leuven, 101-142.

26. Dufour, J. M., \& Dagenais, M. G. (1985). Durbin-Watson tests for serial correlation in regressions with missing observations. Journal of Econometrics, 27(3), 371-381.

27. Edwards, J. R. (2001). Ten Difference Score Myths. Organizational Research Methods, 4(1), 265-287. https://doi. org/10.1177/109442810143005

28. Fairchild, A. J., \& Mackinnon, D. P. (2009). A General Model for Testing Mediation and Moderation Effects. Society for Prevention Research, 10(2), 87-99.

29. Gardner, T. M., Moynihan, L. M., Park, H. J., \& Wright, P. M. (2001). Beginning to unlock the black box in the HR firm performance relationship: The impact of HR practices on employee attitudes and employee outcomes. CARHS Working Paper Series, 1-43.

30. Gerhart, B. (2005). Human resources and business performance: Findings, unanswered questions, and an alternative approach. Management Revue, 16, 174-185.

31. Gilbert, C., De Winne, S., \& Sels, L. (2010). The Influence of line managers and HR department on employees' affective commitment (Catholic University of Leuven (KUL) MO Working Paper (No. 1004)).
32. Gonçalves, P. S., \& Neves, J. (2012). The Link between perceptions of Human Resources Management practices and employee well-being at work. Advances in Psychology Study, 1(1), 31-39. Retrieved from http://hdl.handle.net/10071/14129

33. Gooderham, P., Parry, E., \& Ringdal, K. (2008). The impact of bundles of strategic human resource management practices on the performance of European firms. The International Journal of Human Resource Management, 19(11), 2041-2056.

34. Gould-Williams, J. (2007).

HR practices, organizational climate and employee outcomes: evaluating social exchange relationships in local government. The International Journal of Human Resource Management, 18(9), 16271647.

35. Gruman, J. A., \& Saks, A. M. (2011). Performance management and employee engagement. Human Resource Management Review, 21(2), 123-136.

36. Guest, D. E. (1997). Human resource management and performance: A review and research agenda. International Journal of Human Resource Management, 8(3), 263-276.

37. Harney, B. (2014). Managerial roles. In P. Flood \& Y. Freeney (Eds.), Wiley Encyclopedia of Management (3rd ed.). Wiley-Blackwell.

38. Harney, B., \& Jordan, C. (2008). Unlocking the black box: line managers and HRM-performance in a call centre context. International Journal of productivity and performance management, 57(4), 275-296.

39. Heider, F. (1958). The psychology of interpersonal relation. New York: Wiley.

40. Hope Hailey, V., Farndale, E., \& Truss, C. (2005). The HR department's role in organisational performance. Human Resource Management Journal, 15(3), 49-66.

41. Hutchinson, S. (2013). Performance management theory and practice. London: Chartered Institute of Personnel \& Development. 
42. Hutchinson, S., \& Purcell, J. (2003). Bringing policies to life: The vital role of line managers in people management Chartered Institute of Personnel Development (CIPD).

43. Hutchinson, S., Kinnie, N., \& Purcell, J. (2002). Bringing Policies to Life: Discretionary Behaviour and the Impact on Business Performance. Bath Conference. University of Bath School of Management.

44. Jyoti, J., \& Sharma, P. (2017). Empirical investigation of a moderating and mediating variable in between mentoring and job performance: A structural model. Journal of Work and Organizational Psychology, 33(1), 55-67. https://doi.org/10.1016/j. rpto.2017.01.002

45. Kehoe, R. R., \& Wright, P. M. (2013). The impact of Highperformance human resource practices on employees' attitudes and behaviours. Journal of management, 39(2), 366-391.

46. Kelley, H. (1973). The process of causal attribution. American Psychologist, 28, 107-128.

47. Kelley, H. H., \& Michela, J. L. (1980). Attribution theory and research. Annual Review of Psychology, 31, 457-501.

48. Kulik, C. T., \& Bainbridge, $\mathrm{H}$. T. (2006). HR and the line: The distribution of HR activities in Australian organizations. Asia Pacific Journal of Human Resources, 44(4), 240-256.

49. Larsen, H. H., \& Brewster, C. (2003). Line management responsibility for HRM: what is happening in Europe? Employee Relations, 25(3), 228-244.

50. Latham, G., \& Ernst, C. (2006). Keys to motivating tomorrow's workforce. Human Resource Management Review, 16(2), 181-198.

51. Liao, H., Toya, K., Lepak, D. P., \& Hong, Y. (2009). Do they see eye to eye? Management and employee perspectives of high-performance work systems and influence processes on service quality. Journal of Applied Psychology, 94, 371-391. http:// dx.doi.org/10.1037/a0013504
52. MacDuffie, J. P. (1995). Human resource bundles and manufacturing performance: Flexible production systems in the world auto industry. Industrial Relations and Labor Review, 48(2), 197-221.

53. MacKinnon, D. P., \& Dwyer, J. H. (1993). Estimating mediated effects in prevention studies. Evaluation Review, 17, 144-158.

54. MacKinnon, D. P., Fairchild, A. J., \& Fritz, M. S. (2007). Mediation analysis. Annual Review of Psychology, 58, 593-614.

55. MacKinnon, D. P., Warsi, G., \& Dwyer, J. H. (1995). A simulation study of mediated effect measures. Multivariate Behavioral Research, 30, 41-62.

56. Macky, K., \& Boxall, P. (2007). The relationship between "highperformance work practices" and employee attitudes: an investigation of additive and interaction Setting the Scene: HRM and Performance effects. International Journal of Human Resource Management, 18(4), 537-567.

57. Martins, L. P. (2007). A holistic framework for the strategic management of first tier managers. Management Decision, 45(3), 616-641.

58. McCarthy, A., Darcy, C., \& Grady, G. (2010). Work-life balance policy and practice: understanding line manager attitudes and behaviors. Human Resource Management Review, 20(2), 158-167.

59. Nehles, A. C., Riemsdijk, M., Kok, I., \& Looise, J. K. (2006). Implementing human resource management successfully: A first-line management challenge. Management Review, 17(3), 256-273.

60. Nehles, A. C., Terhalle, A. M., van Riemsdijk, M., \& Looise, J. C. (2010). Line managers as implementers of HRM: are they effective? Manuscript under review.

61. Nishii, L. H., \& Wright, P. M. (2008). Variability within organizations: implications for strategic human resources management. In D. B. Smith
(Ed.), The People Make the Place: Dynamic Linkages between Individuals and Organizations (pp. 225-48). New York: Lawrence Erlbaum Associates.

62. Nishii, L. H., Lepak, D. P., \& Schneider, B. (2008). Employee attributions of the "why" of HR practices: Their effects on employee attitudes and behaviors, and customer satisfaction. Personnel Psychology, 61, 503-545.

63. Ogbuanya, T. C., \& Chukwu, S. O. (2017). Job crafting-satisfaction relationship in electrical/ electronic technology education programme: Do work engagement and commitment matter? Journal of Work and Organizational Psychology, 33, 165-173. http://dx.doi.org/10.1016/j. rpto.2017.09.003

64. Ostroff, C., \& Bowen, D. E. (2016). Reflections on the 2014 decade award: is there strength in the construct of HR system strength? Academy of Management Review, 41(2), 196-214.

65. Paauwe, J. (2009). HRM and performance: Achievements, methodological issues and prospects. Journal of Management Studies, 41(1), 129-142.

66. Paauwe, J., \& Richardson, R. (1997). Introduction special issue on HRM and Performance. The International Journal of Human Resource Management, 8, 257-262.

67. Piening, E. P., Baluch, A. M., \& Ridder, H. G. (2014). Mind the Intended-Implemented Gap: Understanding Employees' Perceptions of HRM. Human Resource Management, 53(4). https://doi.org/10.1002/hrm.21605

68. Preacher, K. J., \& Hayes, A. F. (2004). SPSS and SAS procedures for estimating indirect effects in simple mediation models. Behaviour Research Methods, Instruments, \& Computers, 36, 717-731.

69. Purcell, \& Hutchinson. (2007) Front-line managers as agents in the HRM-performance causal chain: theory, analysis and evidence. Human Resource Management Journal, 17, 3-20. 
70. Purcell, J. (2002). Sustaining the HR and Performance Link in Difficult Times. CIPD Conference. Harrogate.

71. Purcell, J., \& Kinnie, N. (2007). Human resource management and business performance. In P. Boxall, J. Purcell \& P. Wright (Eds.), The oxford handbook of human resource management.

72. Purcell, J., Kinnie, N., Hutchinson, S., Rayton, B., \& Swart, J. (2003). Understanding the people and performance link: unlocking the black box. London: Chartered Institute of Personnel and Development.

73. Salancik, G. R., \& Pfeffer, J. (1978) A social information processing approach to job attitudes and task design. Administrative Science Quarterly, 23(2), 224-253.

74. Sanders, K., Dorenbosch, L., \& Reuver, R. (2008). The impact of individual and shared employee perceptions of HRM on affective commitment. Considering climate strength. Personnel Review, 37(4), 412-425.

75. Sanders, K., Shipton, H., \& Gomes, J. (2014). Guest editors' introduction: Is the HRM process important? Past, current and future challenges. Human Resource Management, 53, 489503.

76. Savaneviciene, A., \& Stankeviciute, Z. (2012a). Human Resource Management and Performance: From Practices Towards Sustainable Competitive Advantage. In Dr. Hector CuadraMontiel (Ed.), Globalization - Education and Management Agendas. InTech. https://doi. org/10.5772/47800

77. Savaneviciene, A., \& Stankeviciute, Z. (2012b). HRM and performance linkage: the role of line managers. Economics and Management, 17(1), 390-396.

78. Schaufeli, W. B., \& Bakker, A. B. (2003). Utrecht work engagement scale: Preliminary manual. Occupational Health Psychology Unit, 1-58.

79. Schuler, R. S. (1992). Strategic human resource management:
Linking the people with the strategic needs of the business. Organizational Dynamics, 19, 18-32.

80. Smith, C. S., \& Tisak, J. (1993). Discrepancy measures of role stress revisited: New perspectives on old issues. Organizational Behavior and Human Decision Processes, 56, 285-307.

81. Smith, D. A., Plowman, A. D., \& Duchon, D. (2010). Everyday Sensegiving: A Closer Look at Successful Plant Managers. The Journal of Applied Behavioral Science, 46(2), 220-244. https://doi. org/10.117710021886310369932

82. Sobel, M. E. (1982). Asymptotic intervals for indirect effects in structural equations models. In S. Leinhart (Ed.), Sociological methodology 1982 (pp. 290-312). San Francisco: Jossey-Bass.

83. Tzafrir, S. S. (2005). The relationship between trust, HRM practices and firm performance. International Journal of Human Resource Management, 16(9), 1600-1622.

84. Tzelgov, J., \& Henik, A. (1991). Suppression situations in psychological research: Definitions, implications, and applications. Psychological Bulletin 109, 524-536.

85. Weick, K. (1979). The social psychology of organizing (Vol. 2). Reading, MA: Addison-Wesley.

86. Whittaker, S., \& Marchington, M. (2003). Devolving HR responsibility to the line: Threat, opportunity or partnership? Employee Relations, 25(3), 245-261.

87. Wright, P. M., \& Nishii, L. H. (2006). Strategic HRM and organizational behaviour: integrating multiple levels of analysis (CARHS Working Paper Series).

88. Wright, P. M., McMahan, G. C., \& McWilliams, A. (1994). Human resources and sustained competitive advantage: a resourcebased perspective. International Journal Of Human Resource Management, 5(2), 301-326.

89. Wright, P., \& Nishii, L. H. (2004). Strategic HRM and organizational behaviour: integrating multiple levels of analysis. Paper presented at the Erasmus University Conference "HRM: What's Next?".

90. Wright, R. M., McCormick, B. Sherman, W. S., \& McMahon, G. C. (1999). The role of human resource practices in petrochemical refinery performance. International Journal of Human Resource Management, 10, 551-571. 